\title{
Evil as a Distortion of Communication: On Hegel's account of Evil as Subjectivism
}

\author{
Martin Sticker
}

\begin{abstract}
The early Hegel's conception of evil draws on a very different paradigm than the current philosophical discourse on evil and therefore challenges received assumptions and can give us fresh impulses. In this paper, I first present Hegel's conception of evil through a close reading of the Jenaer Realphilosophie's, prima facie, obscure claim that evil is the 'internal actual, absolute certainty of itself, the pure night of being for itself'. Hegel discusses evil because he worries how Romanticism and the romantic ideal of authenticity impact the possibility of communication. I then develop the idea that evil is a distortion of communication. I argue that this account of evil helps us to distinguish between evil and mere moral badness. Finally, I address two problems for this account, and discuss its limits.
\end{abstract}

Philosophical theories of evil are often shaped by what a theorist takes to be a paradigmatic case of evil. There are a number of reoccurring and influential paradigms of evil in the history of Western thought: Satan, a non-human source of seduction; the earthquake of Lisbon, a natural evil; Hitler, Stalin or famous serial killers, war criminals or psychopaths, the chief contemporary examples for moral evil. In the present paper, I focus on a conception of evil that is oriented on a paradigm of moral evil that differs notably from all these, namely, on a man named Friedrich Schlegel.

What did Schlegel do? Was he a psychopath, a tyrant, a German Jack the Ripper or a war criminal? Far from it. Schlegel wrote novels and philosophical reflections in the form of fragments, as well as treatises on foreign languages and cultures. Due to its praise of romantic love and disregard for traditional conceptions of marriage, Schlegel's most famous work, the novel Lucinde, was considered frivolous and scandalous at the time. However, this hardly warrants that we characterize its author as evil. Yet, Schlegel served as G W F Hegel's paradigm of evil because of what he stood for: Romanticism and romantic irony, which Hegel considered to be an expression of unchecked and excessive subjectivity. ${ }^{1}$

1 That Schlegel's Romanticism was the main target of Hegel's conception of evil is well established in the literature, see for instance Otto Pöggeler, Hegels Kritik der Romantik (Bonn: Bouvier, 1956), pp. 
In the current paper, I explain why Hegel thinks Romanticism is evil. I then develop the theory of evil that underlies Hegel's criticism of Romanticism, largely independently of its original target. My main focus in this paper is the idea that we can understand evil as a distortion of a form of communication. This is a novel account of evil in its own right and one that can shed light on the nature and sources of evil. Hegel's conception of moral evil draws on a very different paradigm than current debates do and discussing Hegel can therefore challenge common assumptions and afford fresh impulses. In a first section, I briefly explain my main concepts and indicate in what sense I draw on Hegel's works. In a second section, I explain the early Hegel's conception of evil via a close textual reading. In a third section, I discuss the strengths of an account of evil as a distortion of communication. In a fourth section, I discuss two problems of this account.

I should note that whilst I start from one of Hegel's own characterizations of evil and draw on his idea that communication is an essential element of human existence, the idea that we can and should understand Hegel's conception of evil as a distortion of communication is my own. Furthermore, I am ultimately interested in developing a novel account of evil. This account picks out an especially interesting kind of deficiency that is different from moral badness, and it helps us understand what the difference between evil and mere moral badness is and what is deficient about evil. In a final section, I will also concede that this account has shortcomings that are finally rooted in Hegel's intriguing, and also bewildering, paradigm for evil. During my investigation, I take four things from Hegel. Firstly, his idea to see evil as an extreme form of subjectivism insofar as this subjectivism encourages agents to find normative content only within themselves and ignore social dimensions of normativity. Secondly, I will develop my account via a close reading of Hegel's dense and challenging characterization of evil in the Jenaer Realphilosophie. Thirdly, I will draw on Hegel's assumption that a specific form of communication is vital to human existence. Fourthly, in the last section, I will draw on a number of elements from the Phenomenology and Hegel's developed system in order to address objections directed against the idea that evil can be understood as a distortion of communication.

Since my investigation is ultimately not in the service of Hegel scholarship but of a better understanding evil, in particular of the idea that evil can be understood as a distortion of communication, I cannot do justice to Hegel's notion of evil as part of his later, more developed system. Obviously, Hegel's conception of evil is much richer than his brief characterization of evil in the Realphilosophie. In his later system it becomes apparent that evil is not a self-standing issue and it is not just a matter concerning the interaction between two (or more) individuals, but also of the interaction between individuals and the system

193-194). See also EPR §140, 265 where Hegel calls romantic irony the 'supreme form' of the expression of subjectivity and considers it the final, and presumably most severe, form of evil. Schlegel does indeed stresses that irony is 'arbitrary' (KA II:160.108) thus indicating that irony is for him a mere expression of subjectivity or of arbitrary preferences. I will say more about Hegel's criticism of Schlegel at the end of sec.II. In what follows, I cite the Elements of the Philosophy of Right according to Hegel (1970) vol.7: EPR Sparagraph, page. My translation follows Wood (1991). I cite Schlegel according to Behler (1979): KA volume:page.fragment. Translations, with occasional modifications, are from Frichow (1971). Translations from the Philosophische Lehrjahre in vol.18 are my own. 
as a whole. Evil arises when the individual mistakes itself to be the absolute and above the system. I will abstract from this since it would go beyond the scope of my paper. Furthermore, abstracting from the systematic context of evil also allows me to sidestep a number of objections often levelled against Hegel's theory of evil, such as that Hegel's notion of evil aims at subsuming the individual under the system or under a collective ${ }^{2}$ or that an account, which conceives of evil as part of a rational system, thereby justifies or condones evil. ${ }^{3}$ These are not problems for my project of developing the idea that evil is a distortion of communication, since such a conception does not have to be part of a system.

The conception of evil I will focus on is located in Hegel's Jenaer Realphilosophie written in 1805/06 and only published posthumously in 1931. The Realphilosophie was written at the same time as the Phenomenology of Mind. In this section, I briefly look at the Phenomenology, the much more prominent text of the two, in order to gain a better understanding of the background of Hegel's thoughts at the time insofar as this will help us understand his notion of evil. Obviously, I cannot even attempt to do the Phenomenology justice here, given that its themes span from perception to self-consciousness, to social philosophy and philosophy of religion and history. In fact, I will focus on one single element in paragraph 69 of the Phenomenology's Preface, since this element is very illustrative of Hegel's philosophical and ethical concerns at the time. Hegel here criticizes appeal to 'feeling, to an oracle dwelling within' ${ }^{4}$ or to immediate certainty as 'trampling the roots of humanity underfoot ${ }^{\prime}$, i.e., as a severe violation of our human nature or of what we, as humans, are capable of and entitled to. Appeals to immediate certainty are supposed to stop a conversation as they are to function as instances of final justification that others cannot object to. ${ }^{6}$ By contrast, it is, according to Hegel:

2 I will, however, show in sec.II and IV that we should not understand Hegel's criticism of subjectivism as him denying the importance and normative standing of subjectivity.

3 See Richard Bernstein, Radical Evil. A Philosophical Interrogation (Cambridge, Polity Press, 2002), p. 75.

4 PoM §69, 64. The extreme form of the internal oracle is the beautiful soul, which Hegel discusses polemically towards the end of the Geist chapter (PoM §658, 483f.). In what follows, I cite the Phenomenology according to Hegel (1970.) vol.3: PoM §paragraph, page. My translation follows Pinkard (2013) with occasional modifications.

5 PoM $§ 69,65$.

6 The person who appeals to immediacy supposes that he 'has spoken of final things against which nobody can object nor beyond which anything more can be demanded' (PoM §69, 64). These final pronouncements can, for instance, take the form of appeals to 'the immediate revelation of the divine' (PoM $\S 68,63)$, as well as to one's 'heart's innocence' and 'purity of conscience' $(\$ 69,64)$. All of these sources escape external scrutiny by others since they are only present within the person who appeals to them. Hegel, by contrast, demands that 'the best' may not be 'hidden away in inwardness; the best was supposed to be drawn up out of that deep well and brought up to the light of day' (PoM §69, 64). See also PoM §10, 17f., §14, $20 \mathrm{f}$. 
the nature [of humanity] to drive men to agreement with one another, and humanity's existence lies only in the commonality of consciousness that has been brought about. The anti-human, the merely animalistic, consists in staying put in the sphere of feeling and in being able to communicate only by means of such feelings. ${ }^{7}$

According to this passage, it is an important, maybe even essential, feature of human existence that we can interact in other ways than through appeal to immediate certainty. We can (and have to) provide reasons and justifications, and these reasons and justifications have to be accessible to others in the sense that they can understand and critically evaluate them. Giving and taking reasons serves to drive men (and women) to an agreement with each other, and this agreement is not the result of force, threat or deception but of insight into the merits and justification of a claim or position. ${ }^{8}$

Hegel's concept of communication as something that is part of the nature of humanity and as something that is supposed to lead to a commonality of consciousness is a much more specific form of what we usually mean by 'communication'. After all, communication that stays 'put in the sphere of feeling' is also communication, but not the kind that Hegel thinks deserves protection and philosophical attention. We can label the communication that lies in the nature of humanity 'communication in a rich sense'. Hegel assumes that the root of humanity consists in striving for agreement ('to drive men to agreement with one another'). This agreement consists in a 'commonality of consciousness' that does not merely occur accidentally when two agents share the same feeling or inner voice, but 'that has been brought about', i.e., one that results from agents striving together for agreement via a mutual exchange of arguments. Communication in a rich sense requires reciprocity between agents engaged in communication with each other and this reciprocity is not merely the reciprocity of two agents communicating their feelings or subjective states to each other. 'Reciprocity' means that agents make normative claims or demands on each other, ask each other for justifications of these claims and demands and, in turn, are willing to support their claims and demands with reasons. Communicating agents are in principle willing to take others' claims and demands into account. They either make these claims their own or provide reasons for why they reject them, and they are open to others' replies.

In what follows, I will argue that we can fruitfully understand evil as a disruption or distortion of communication in the rich sense just outlined. Whilst Hegel himself does not explicitly say this, I suggest that we use his claim about the root of humanity to understand why he objects to certain forms of subjectivism as evil. The reason for this is that his objection might otherwise appear mysterious, and to fuel long-standing concerns that Hegel is an anti-individualistic thinker who wants citizens to defer mindlessly to the

\footnotetext{
7 PoM §69, 65.

8 The central role communication plays for the Phenomenology also becomes apparent in Hegel's various discussions of language the element in which the fulfilling sense is present (PoM §695, 510) and which can reveal what otherwise remains internal (PoM §696, 511). See also PoM §710-2, 518-21, §726ff., 528ff. In Martin Sticker, 'Hegel und die Wurzel der Humanität', Hegel Jahrbuch (forthcoming) I discuss in more detail Hegel's notion that communication and striving for agreement is the nature of humanity. I show how this notion informs the entire Phenomenology but also criticize that Hegel fails to do justice to the phenomenon of rational disagreement as another essential feature of human communication.
} 
community or to state authority. Focus on the phenomenon of communication in a rich sense helps us to make sense of Hegel's early conception of evil as well as allows us to explain why he saw something wrong with certain forms of subjectivism.

Before I outline the Realphilosophie's conception of evil in the next section, let me stress that I do not claim that evil is a disruption of communication in a sense other than in the rich sense I outlined. Communication is a broader phenomenon than the reciprocal exchange of reasons. Issuing orders and commands, certain expressions of politeness, discussing merely technical (non-normative) matters, etc. are all forms of communication, albeit not in the rich sense that, according to Hegel, is characteristic of human existence. Unless otherwise specified, I will mean by 'communication' communication in a rich sense. Communication, as I use the term, thus requires the possibility of an exchange of normative claims or that all agents involved in communication are, in principle, willing to take into account what others have to say and willing to make their normative claims their own if they find them convincing. 'Normative claims' here is intended as a somewhat clumsy catch all for that which is given and exchanged in communication in a rich sense: requests, demands, reasons, arguments, etc.

To give a brief example of what I mean by communication in a rich sense as opposed to other communication: Imagine I order my employee to perform a task and she tells me that she will not do it because this is not part of her contractual obligations; it would require overtime work without pay; it is unfair that this chore once again rests with her, etc. We are communicating in a rich sense if I take her objections into account and either change my mind; or point out that in fact it is part of her contractual obligations (I acknowledge that the contract binds both her and me); I offer overtime pay (I acknowledge that making my employees work overtime require that I compensate them accordingly); I point out that in fact it is her turn to do it this time (I acknowledge that my orders must be fair). We do not communicate in a rich sense if I give her the order and then just walk back to my office and shut the door without listening to her; only engage with her objections on a superficial level; answer that I don't want to hear any complaints; ask her why she must always complain. ${ }^{9}$ Communication in a rich sense allows for hierarchies and asymmetries but not for lack of rational engagement with others. I should also note that not everyone who (occasionally) refuses to communicate in the rich sense qualifies as evil. Only an agent who has made it the centre of her identity not to communicate in a rich sense does.

Communication in a rich sense matters for my discussion for two reasons. Firstly, as I explained, Hegel himself acknowledges that there is something very significant about our ability to communicate with each other: it is part of the nature of humanity. Understanding evil as a disruption of communication thus offers an exegetically grounded way to revisit and reconsider Hegel's conception of evil based on a concern that even those who do not buy into Hegel's system can share. After all, that demanding and giving

\footnotetext{
9 Of course, matters are potentially more complicated than I presented them. What if the task is clearly part of the contract, does not require overtime and it is the employee's turn and she does complain every single time she has to do something? In this case, it might be appropriate to tell her to stop complaining, if I have in the past pointed out to her why something is her contractual duty, part of the normal work day, and under what conditions it is fair to give her the task, and if I was willing to listen to her objections then. Communication in a rich sense does not require that we have the same conversation over and over again.
} 
reasons and asking for justifications is something fundamentally human seems uncontentious. Secondly, one central aspect of communication is that it allows us to criticise other agents and even potentially to change their minds. According to my analysis, evil agents cannot be criticised in the same way as non-evil agents. There is (almost) nothing to be gained by criticising evil agents. Looking at how we can criticise agents will help us to distinguish between morally bad, evil and insane agents.

II

Hegel's early account of evil, on which I focus, is largely neglected in the Hegel literature as well as in in the literature on evil. This is presumably due to its relative obscurity as well as because it stands in the shadow of Hegel's more mature account of evil, which can be found, for instance, in the Elements of the Philosophy of Right. Furthermore, despite Hegel offering the densest possible characterization of his early conception of evil in the Jenaer Realphilosophie, he does almost nothing to develop it here. In what follows, I will use the Phenomenology to elucidate this dense characterization, since there are many parallels between the Realphilosophie and the Phenomenology.

In the Jenaer Realphilosophie (JR) Hegel characterises moral evil as 'internal actual [ii], absolute certainty of itself [iii], the pure night [iv] of being for itself [i]'. ${ }^{10}$ In this section, I interpret and explain this dense characterization.

[i] Being for itself: Being for itself is the subject of this account of evil. The other three components of the account are characteristics of a being for itself, which is evil. The context, as well as other passages, show that 'being for itself' here refers to an agent's selfconsciousness. ${ }^{11}$ Evil is a property of self-conscious agents or, more precisely, of their attitudes towards themselves and of how they understand the normative authority of their selves. ${ }^{12}$ In what follows, I will simply speak of an evil agent, but strictly speaking evil pertains to the self-consciousness of this agent. An agent be characterized as evil if he has the following three characteristics.

[ii] Internal actual: 'actual' [Wirklichkeit] for Hegel does not refer to what merely exists, but to the rational or justified part of what exists, as it is apparent form Hegel's

10 'innerliche Wirkliche, absolute Gewißheit seiner selbst, die reine Nacht des Fürsichseins'. This characterization occurs in G. W. F. Hegel, Gesammelte Werke (Hamburg: Meiner Verlag, 1968ff.), vol. 8, p. 256 separated in two different margins. The edition G. Göhler, Georg Wilhelm Friedrich Hegel. Frühe politische Systeme (Frankfurt a.M.: Ullstein, 1974), published two years before vol.8 of the Gesammelte Werke, puts it in the main text (p. 262) and as one sentence. In what follows, I will quote the Realphilosophie, according to Gesammelte Werke vol.8 and also provide the page numbers of the Göhler edition. JR translations are my own.

11 Cf. PoM §186, 147: 'Self-consciousness is at first simple being-for-itself'. The idea that evil is a property of self-consciousness is also maintained in Hegel's later works - cf. EPR §139, $260 f$.

12 The attribution of evil to agents, as opposed to actions or their outcomes, is further warranted by JR 250 margin/258. Treating evil as a property of something other than actions, e.g., of the character, the person, or the agent is a widely accepted view. Cf. for instance Claudia Card, The Atrocity Paradigm (New York: Oxford University Press, 2002), p. 22, Adam Morton, On Evil (New York: Routledge, 2004). Others, however, do consider evil a property of actions (see for instance Paul Formosa, 'A Conception of Evil', The Journal of Value Inquiry 42:2 (2008), pp. 217-239). 
famous Doppelsatz: 'What is rational is actual; and what is actual is rational'. ${ }^{13}$ The first characteristic of an evil agent is that what is actual or rational and justified for him is internal. An evil agent takes what is internal to him, or subjective, as a source of justification of his actions. Hegel therefore also writes that evil is 'divided from the universal'.$^{14}$ In the preface of the Phenomenology, Hegel's example for such an internal actual, is, as we have already seen, the 'internal oracle' 15 , which he identifies with an agent's immediate feeling that something is right. The problem with taking one's immediate feeling that something is right as a source of justification is that the justificatory force of the immediate feeling depends on the presence of this immediate feeling within an agent. There is no way for an agent to rationally convince another agent to have or share this immediate feeling. An agent either has such a feeling or he does not. ${ }^{16}$ Anything an agent becomes convinced of as a result of arguments presented to her would not come as an immediate certainty. Appeals to one's subjectivity can thus constitute appeals to immediacy and disrupt communication understood as an exchange of reasons and arguments.

However, we should bear in mind that subjectivity for Hegel is a necessary moment of agency and a guiding principle specifically of modern societies. Justifying claims by appeal to one's subjectivity is legitimate in many circumstances, such as in matters of taste and personal lifestyle choices. Hegel is primarily worried about the Romanticist ideal of authenticity since it overemphasizes the normative significance of subjectivity. ${ }^{17}$

The kind of 'internal actual' that is problematic for Hegel is most clearly presented in the Phenomenology's discussion of conscience. ${ }^{18}$ There Hegel identifies a determination by one's internal law with determination by one's 'singularity' [Einzelnheit] ${ }^{19}$ and 'arbitrariness' [Willkür] ${ }^{20}$. Being determined by one's internal law is for Hegel a violation of what is universally recognized. ${ }^{21}$ 'Singularity' refers to a source of supposed justification, such as idiosyncratic personal convictions that the agent is certain of immediately and which he cannot justify to others and yet refuses to give up. An agent's singularity is private in the sense that other agents have no influence over what the content

13 EPR Preface, 24.

14 JR 249 margin/ 257.

15 PoM $\$ 69,64$.

16 PoM §69, 64f.

17 The most extensive and recent defence of Hegel against the charge that he is an enemy of subjectivity is Dean Moyar, Hegel's Conscience (Oxford: Oxford University Press, 2011). According to Moyar, Hegel's political philosophy explicitly aims to make room for subjectivity.

18 The tight connection between conscience and evil is maintained in Hegel's later writings. Cf. EPR \$139. Moyar, Hegel's Conscience presents an elaborate argument that Hegel also envisioned a positive role for conscience. Whilst Hegel was dismissive of formal conscience, he 'unambiguously defends a view of conscience that he calls 'actual conscience" (Moyar, Hegel's Conscience p. 72).

19 The standard translation of 'Einzel(n)heit' is 'individuality'. This is inadequate since it does not allow us to distinguish between 'Einzelheit' and 'Individualität'. I will therefore use the more literal term 'singularity' as a translation of 'Einzel(n)heit'.

${ }^{20}$ Due to this arbitrariness conscience as a source of justification can, in principle, justify any action. Other agents therefore 'do not know whether this conscience is morally good or evil; or to an even greater degree, not only can they not know this, they must also take it to be evil' (PoM §649, 477f.). 21 PoM §662, 486., cf. also JR 250 margin/258. 
of this singularity is, i.e., they cannot talk an agent out of something he finds within his singularity. Others' normative claims are completely irrelevant to an agent's singularity because these claims do not stem from this singularity and an agent's singularity does not acknowledge any normative authority other than its own.

Hegel believes that appeals to feeling of certainty, internal oracles, conscience and authenticity are appeals to one's singularity. If they were more than appeals to one's singularity then agents could and would be willing to justify their claims in a proper discursive form (as opposed to insisting on the immediate certainty of these claims). The following two components, [iii] and [iv], of Hegel's account of evil specify an attitude of an agent towards his subjectivity, which leaves no room in an agent's deliberations for external input (exclusivity) and which lets an agent attach absolute confidence to his own subjectivity (immediate certainty). This, Hegel believes, turns appeals to subjectivity into appeals to singularity. ${ }^{22}$

[iii] Absolute certainty of itself: An evil agent attaches absolute credence to his subjectivity. For an evil agent, a normative claim is justified beyond doubt if it stems from his subjectivity. The agent is certain that his subjectivity cannot go wrong and can justify all kinds of claims, not only those regarding taste or personal lifestyle choice, i.e., for instance moral claims or claims concerning what he is entitled to. An agent is certain of claims if they feel right to her. This right feeling should be understood in a broad sense. The examples from the Phenomenology indicate that such a feeling can stem from a supposed divine command (internal oracle), supposed moral convictions (conscience), or other personal beliefs and goals. Feeling, in this sense, is everything that seems immediately correct or evident to the agent and that he thus believes without second-guessing and not based on other, intersubjectively shareable, evidence or reasons.

[iv] Pure night: Following my reading of [i-iii] the metaphor of the pure night can be understood as referring to the attitude of an evil agent to sources of justification other than his subjectivity. A pure night is literally a night exhibiting nothing but the characteristic property of a night: darkness. ${ }^{23}$ This is an inhibition of vision that makes it impossible to gain information about the external world. It is a state in which an agent falls back on his internal actual because his access to what is external to him is inhibited. Insofar as an evil agent takes a normative claim to be justified, this justification cannot come from an external source but comes from the approval of his subjectivity. The evil agent does not consider anything as conferring normative standing other than the immediate conviction that something is right.

Hegel also refers to evil as 'the pure knowledge of oneself' 24 , i.e., as knowledge of nothing but one's subjectivity. This claim is prima facie puzzling since self-knowledge is usually seen as something good and extremely important. ${ }^{25}$ Hegel's remark makes sense if

\footnotetext{
22 That evil is a specific attitude towards one's subjectivity is also maintained in Hegel's more mature writings. Cf. EPR §139, 260-1. Hegel thinks that it is a specifically modern form of evil when 'subjectivity declares itself absolute' (EPR §140, 265).

23 In JR 252 margin/260 Hegel calls evil 'this darkness of man in itself'.

24 JR 252 margin/260.

${ }^{25}$ Hegel even calls the command to know thyself an 'absolute command' (Enz \$377, 9). I cite the Encyclopedia according to Hegel (1970) vol.10: Enz §paragraph, page. Translations are my own.
} 
we understand it not as a warning against knowing oneself, but as a warning against knowing nothing but oneself or against failing to engage and communicate with other agents and learning about them (their views, projects, claims, etc.).

Evil, according to Hegel, should be understood as a property of a self-conscious agent [i], who takes her subjectivity to be a source of justification [ii] of a specific kind. An evil agent rests sure in her arbitrary convictions (immediate certainty) [iii] and other agents as well as institutions and the community lack means to correct or rationally influence this agent and to provide normative input into her deliberations (exclusivity) [iv]. This agent is not merely someone who values her subjectivity, after all subjectivity has its rightful place, but someone who is obsessed with her singularity, i.e., with a supposed source of normative claims that is beyond rational criticism and the claims of which cannot be justified to others. Evil is the inability of stepping out of oneself and of seeing oneself from another perspective, which one acknowledges as rational or normative. Evil can be understood as a disruption of communication because an evil agent does not take the normative claims of others into account and does not respond to them as normative claims, i.e., as potential reasons to change his mind. An exchange of normative claims with such an agent is not possible. Other agents cannot function as a corrective for this agent and this is what makes his views and goals potentially so dangerous. Evil agents do not accept any externally imposed limits. ${ }^{26}$

Before we move on to a discussion of the strengths and weaknesses of the notion of evil as a disruption of communication let me briefly say something about Hegel's paradigm for evil, Friedrich Schlegel. I believe that Hegel does present a serious challenge to the ideal of authenticity, insofar as this ideal expresses purely subjective preferences, and as long as there is no need to justify oneself to others in an authentic life. However, Romanticism cannot be reduced to this ideal. This is particularly apparent for Schlegel himself. The truly ironic person is more distanced from the concrete features of her subjectivity than the evil person is according to Hegel. For her, her power to set ends is more fundamental than whatever those ends happen to be and she is well aware of the contingency of each end, even from her own point of view. ${ }^{27}$

The consensus in the Romanticism literature on the dispute between Hegel and Schlegel is that Hegel got Schlegel 'badly wrong' 28 and that he misreads Schlegel as a pure subjectivist and irresponsible free thinker. ${ }^{29}$ Schlegel is not an anti-systematic thinker who

26 Of course, agents who do accept external limits can still be very bad. After all, the limits might be unjustified (for instance deferring to a Führer might be an appeal to external limits). It should also be noted that some supposed appeals to external limits, such as divine command, are for Hegel better understood not as appeals to external limits but as appeals to an internal oracle.

27 I am grateful to Seiriol Morgan and Nadine Köhne for pressing me to distinguish between irony and authenticity as possible targets of Hegel's criticism.

28 Judith Norman, 'Squaring the Romantic Circle', Proceedings of the Hegel Society of America 14 (2000), pp. 131-144, at p. 131.

${ }^{29}$ Frederick, Beiser, The Romantic Imperative. The Concept of Early German Romanticism (Cambridge, Mass.: Harvard University Press, 2003), p. 2 stresses that it was the goal of Romanticism to 'reconcile the demands of community and those of individual liberty' not to deny any role to society. Furthermore, he argues that Schlegel endorsed romanticism chiefly because of its (anti-Fichtean) 'antifoundationalism' (ibid.108). Schlegel, indeed, stresses that philosophical principles 'are always in a plural', and he criticises the 'foundation-mad' philosophers such as Fichte (KA XVIII:105.910, see 
wants to surrender philosophy, society and life-choices to arbitrariness, subjectivity or one's singularity. ${ }^{30}$ For Schlegel 'Philosophy is the real homeland of irony', since 'wherever philosophy appears in oral or written dialogues [...] there irony should be asked for and provided' ${ }^{31}$ Irony here is not supposed to function as an appeal to immediacy but rather as something that fosters dialogue among rational agents. ${ }^{32}$ Schlegel even claims that 'Doing philosophy means searching for omniscience together'. ${ }^{33}$

Hegel's conception of evil might not fly as a criticism of early Romanticism, given that the Romantics are not necessarily committed to the unchecked subjectivity Hegel makes the target of his conception of evil. However, this still leaves us with the question of whether Hegel presents an interesting conception of evil that helps us understand the phenomenon. In what follows, I discuss the idea that evil is a distortion of communication, which I suggested is a fruitful way of understanding Hegel's conception of evil and concerns with Romanticism.

\section{III}

The conception of evil I developed in the previous section has the potential to give us a neat distinction between evil and moral badness. This is important, because, according to a wide-spread intuition, evil is different from mere moral badness. ${ }^{34}$ A philosophical

also KA XVIII:518.16). Hegel himself was an anti-foundationalist, as becomes apparent in his critical discussion of Reinhold's 'Grundsatzphilosophie' in PoM \$19, 20, §24, 27f. Hegel thus presumably shared at least some of the concerns that led Schlegel to endorse Romanticism. For further defence of romantic irony against Hegel see Norman, 'Squaring the Romantic Circle', and Martin Sticker and Daniel Wenz, 'System und Systemkritik - Witz und Ironie als philosophische Methode beim frühen Friedrich Schlegel', Philosophisches Jahrbuch 120:1 (2013), pp. 64-81, sec.2.

30 See for instance KA II:173.53.

31 KA II:152.42.

32 In his critical discussion of irony, Hegel distinguishes between Plato's conception of irony as a way to engage others in dialogue and Schlegel's romantic iron. He takes no issue with the former and only sees the latter as something that is intended as an attempt to present an ultimate justification ('the ultimate factor') in the form of appeals to one's subjectivity (EPR \$140, 277). It seems, however, that Schlegel's conception of irony might rather fit the bill of platonic irony than Hegel's conception of romantic irony. See Bärbel Frischmann, Vom transzendentalen zum frühromantischen Idealismus. J.G. Fichte und Fr. Schlegel (Paderborn: Schöningh, 2005), p. 332 for a conception of irony according to which irony is a personal ideal of self-perfection and self-distance, not simply an expression of arbitrariness. In the literature many authors concur that Schlegel was no anti-systematic thinker who advocated unchecked subjectivism and arbitrariness, but rather someone who championed a distinct form of dialectic. See for instance, Mandfred Frank, 'Philosophische Grundlagen der Frühromantik', Athenäum, 4 (1994), pp.37-130, at pp. 126-30, Rüdiger Bubner, 'Zur Dialektischen Bedeutung romantischer Ironie', in Innovationen des Idealismus, edited by Rüdiger Bubner (Göttingen: Vandenhoeck \& Ruprecht, 1995), pp. 152-163, Sticker, Wenz, 'System und Systemkritik'.

33 KA XVIII:515.97, see also KA II:160.108.

34 Paul Formosa, 'Evils, Wrongs and Dignity: How to Test a Theory of Evil', The Journal of Value Inquiry 47:3 (2013), pp. 235-253 for instance argues that evil is "a different moral category" than mere badness. See also John Kekes, Facing Evil (Princeton: Princeton University Press, 1990), p. 49, Susan Neiman, Evil in Modern Thought. An Alternative History of Philosophy (Princeton, Oxford: Princeton 
conception of evil should be able to explain how evil differs from mere badness or wrongdoing.

We can understand how evil as a distortion of communication captures this difference if we look at deliberation. Morally bad agents tend to accord an undue weight to certain normative claims, usually their own, sometimes also claims of members of their gang or criminal organisation, members of the same race, gender, etc. ${ }^{35}$, and they act based on their biased deliberations. ${ }^{36}$ This, however, does not mean that they attach no weight to normative claims of others. Even a morally bad agent recognizes that others' claims as well as universally recognized norms count for something, even if these do not stem from their own subjectivity. An evil agent, by contrast, never takes into account normative claims from sources other than his subjectivity. The evil agent does not attach a special weight to his own normative claims; rather, he attaches no weight at all to other claims. These other claims do not enter his deliberation. The evil agent is not biased but fundamentally ignorant. ${ }^{37}$

This way to distinguish between bad and evil has three implications:

(i) The morally good and the morally bad agent have in common that their deliberations are complex. The morally bad agent takes into account claims justified by a wide range of sources and has to rank these claims or weigh them against each other. His deliberations work like the deliberations of the morally good agent except that he commits occasional or frequent mistakes in the weighing of different claims against each other. The normative deliberations of the evil agent, by contrast, are simple since he only takes into account claims from one source. The evil agent does not worry about questions of commensurability, such as what weight to attach to his self-interest, needs of others, special obligations to loved ones, universally recognized norms, rights, etc. His deliberations are simply determined by his singularity. Whatever he is immediately certain of, what feels right to him, he takes as sufficiently justified no matter what. It might therefore even be

University Press, 2002), p. 8., Roy Perrett, 'Evil and Human Nature', The Monist 85:2 (2002), pp. 30419, at pp. 304-305 for the distinction between evil and moral badness.

35 There are of course many difficult issues here, such as: Is it undue to attach more weight to the claims of loved ones? Answering this question presupposes a detailed discussion of the moral status of personal relationships, which I cannot embark on here. Furthermore, I do not claim that agents are either morally bad or morally good - this would be a very 'unhegelian' dichotomy. A clear case of a morally bad agent is someone whose actions are always shaped by her conviction that she counts for more than others. Many actual agents deserve a more nuanced characterisation.

36 Of course, this is just one kind of moral badness. Another prominent one would be weakness of will - an agent reaches an unbiased judgment but is then overwhelmed by passions and acts against his own judgment. I will focus on moral badness as it manifests itself in deliberation so as to clearly contrast badness with evil.

37 That evil agents exhibit a 'total failure to see that certain considerations are reasons at all' is sometimes called 'psychological silencing' (Eve Garrard, 'Evil as an Explanatory Concept', The Monist 85:2 (2002), pp. 320-336, at pp. 329-330). Things that otherwise would constitute reasons, such as ' $\mathrm{t}$ ] he sufferings of his victims, along with other considerations such as their rights, play no part in [the evil agent's] practical deliberations. They count for nothing at all. And it is this silencing, this inability to hear the victims' screams as significant, that accounts for the peculiar horror that we feel when we contemplate these evil acts and their agents' (Eve Garrard, 'The Nature of Evil', Philosophical Explorations 1:1 (1998), pp. 43-60, at pp. 53-4). 
incorrect to say that the evil agent deliberates, if by 'deliberate' we mean a weighing of pros and cons. The evil agent rather listens to himself until he becomes certain of something without engaging in critical deliberation in the normal sense. One of the attractions that being evil has for evil agents is that it makes decisions very simple and seemingly allows agents to sidestep many difficult issues. ${ }^{38}$ One of the characteristics of evil that evil as a distortion of communication successfully captures is that evil can result from, or be accompanied by, a form of thoughtlessness or overly simplistic worldview that is ignorant of important aspects that are obvious to everyone but the evil agent.

(ii) We can communicate (in a rich sense) with bad agents but not with evil ones. A bad agent will take the claims we articulate to him into account - although often not to the extent that he should. We can argue with a bad agent, try to show him that he has attached an undue weight to certain claims, and point out why he should not have done so. The bad agent will then either admit his mistake, or, more likely, deny that he attached an undue weight, or try to justify his way of deliberating and acting to others. An exchange of normative claims with the bad agent is possible, he is willing to enter the process of reasongiving-and-taking. The evil agent, however, sees no need to enter this process or to take objections into account. The only way for such an agent to be criticised by other agents is when the claims of other agents happen to correlate with claims that also have the backing of the evil agent's singularity. Whether they do, however, is a matter of pure chance, and is independent of how good the respective claims are justified from an objective or intersubjective perspective. The conception of evil as distortion of communication does capture that evil is often not just a matter of great harm but inflicted by people who cannot be swayed by rational argument or by anything the victims of evil or anyone else could say.

It is still possible, though, to criticise an evil agent internally by taking his own claims and beliefs for granted and pointing out internal inconsistencies - if there are indeed inconsistencies. ${ }^{39}$ The possibility of criticising the evil agent internally, however, is not sufficient to constitute communication. Internal criticism can, at most, bring the agent to exchange one of his idiosyncratic beliefs for another. This means that occasionally we will get the impression that an evil agent reacts to us in the right way, i.e., that he takes our claims into account, but in fact he is still determined by his singularity. I will say more about this below (sec.IV.i) when I discuss the difference between evil and insanity.

\footnotetext{
38 Of course, there could be marginal cases: Take an agent who does extreme harm to others for a trivial personal gain but would not have inflicted the harm if the expected gain was just a little more trivial than it already was. Such an agent does acknowledge others' rights and claims but assigns such a minimal weight to them that he collapses the distinction between moral badness and evil. I am open to that. In fact, Hegel's problem is rather that there is too much divergence between evil and moral badness than too little (see sec.IV.ii). I am grateful to Seiriol Morgan for raising this point.

39 It might also sometimes be appropriate to criticise evil agents from an external perspective not because we can hope that the evil agent will change her mind or even respond to us, but in order to demonstrate to a third party that a certain form of behaving is not on. I am grateful to Seiriol Morgan for alerting me to this point.
} 
(iii) Evil as a distortion of communication also accommodates the wide-spread intuition that evil agents, in contrast to morally bad ones, cannot feel shame or remorse. ${ }^{40}$ An evil agent does not understand that anything he did, said or believed, was objectionable because it was unobjectionable to him and nothing else matters to him. He sees no need to reconsider his position in the light of the normative claims of other agents, because he sees no point in these claims. In fact, he cannot even recognize them as genuinely normative.

\section{IV}

I will now discuss the two main problems of the Hegelian account of evil I developed. These problems are (i) that it might look as if the evil person is insane rather than evil, and (ii) that 'evil' might be a stark exaggeration as a label for the deficiency the account captures. I do not think that Hegel has the resources to give a completely satisfying response to the latter objection. Nonetheless, I believe that discussing these objections does not only reveal weaknesses of Hegel's theory of evil but also some important features for our theorizing about evil. Before I discuss these objections, I will briefly address one other issue.

From what I argued so far one might get the impression that Hegel's theory of evil denies something that is (almost) trivially true. Isn't it obviously the case that all claims we take to be valid or action guiding for us are claims that we also subjectively approve of? When Hegel worries about agents who only take into account that which stems from their subjectivity, is he implying that agents can take into account claims their subjectivity does not approve of, and even that they should do so? Surely, this cannot be required of agents. It is clear for Hegel that for a claim to be normative for a (modern) individual, this individual herself must accept the claim. This acceptance, however, does not have to be the approval of the agent's singularity. Evil means that we accept claims as beyond doubt because our singularity approves of them in the sense that they feel immediately right (immediate certainty) and that we do not accept anything else and do not have any doubts about them (exclusivity). However, it is not the case that everything we subjectively accept is immediately certain to us, nor is everything we accept ultimately rooted in private and idiosyncratic ideas that we cannot justify to others. Evil is a specific attitude that agents have towards themselves and we can be subjectively convinced of something without taking up this attitude. Furthermore, often we are aware that what we believe could be false and we are aware of reasons that count against our beliefs, but yet we take these beliefs to be, on balance, better justified than competing beliefs. Such an attitude of accepting something cautiously and on balance is alien to an evil agent.

Let us now turn to the two deeper problems. (i) It seems that an evil agent on the conception of evil as distortion of communication is completely caught up in her own system of idiosyncratic beliefs and is unable to be corrected by others. The medical term for such an agent would presumably be 'insane'. This is a problem for two reasons. Firstly, 'evil' might be a superfluous concept if it is merely a different word for a psychological or

40 Cf. also Perrett, 'Evil and Human Nature', p. 304 and Brian Barry, 'Extremity of Vice and the Character of Evil', Journal of Philosophical Research, 35 (2010), pp. 25-42, at p. 30 who stress this element of evil. 
pathological condition. Secondly, insane people are commonly considered unaccountable for their deeds. It would be odd if evil got agents, morally and legally, of the hook.

Let me begin my response with two remarks: Firstly, the proximity between 'evil" and 'insane' might not be coincidental for Hegel, given the target he has in mind. Some of the Romantics he criticised, such as Hölderlin, struggled with mental illness ${ }^{41}$, and many of them were very interested in phenomena, such as mental illness, depression, suicide, etc. Hegel calls madness ('Verrücktheit') the reign of the 'evil genius of man' ['böse Genius des Menschen'] ${ }^{42}$ Clearly, he thought that evil and insanity overlap at least partly. Secondly, it might be unfair to press Hegel or Hegelian theories of evil too hard here, given that the problem that there is no clear-cut distinction between evil and insanity is not just a problem for these theories but rather is rooted in the very phenomenon. It seems that many paradigms of evil agents, such as Hitler, Stalin, serial killers, could also serve as paradigms for forms of mentally illness. In fact, many paradigms of moral evil have been studied by psychologists because of their (alleged or real) mental illnesses.

Still, this leaves us with the question of what the difference might be between evil and insanity. We can draw a distinction by looking at how we can and cannot criticise evil and insane persons respectively. Non-evil agents (good and bad ones) can be criticised internally as well as externally. As I already argued, evil agents can still be subject to internal criticism (sec.III.i) in the sense that such a form of criticism could change an evil agent's mind. Insane people, by contrast, are not even susceptible to internal criticism. They are not susceptible to criticism at all. Insanity means that a person is so completely caught in her own web of beliefs that the web is even resistant to the charge of internal contradiction. A truly insane person either does not worry about contradictions ${ }^{43}$ or, when an internal contradiction is pointed out to her, she does not see this as a problem for retaining her beliefs, since she will simply make up ad hoc assumptions and explanations to smooth over the internal tension. With an evil agent I can only discuss in her own terms (and this does not constitute communication in the rich sense), with an insane agent I cannot discuss at all. The way to distinguish between evil and insanity is asking the

${ }^{41}$ In his famous description of the beautiful soul, Hegel makes an oblique reference to the way Novalis died from tuberculosis, when he claims that the beautiful soul "melts into a yearning tubercular consumption" (PoM §668, 491). Hegel here makes a pun based on the German term for "consumption", "Schwindsucht", which is also a colloquial term for tuberculosis. Hegel thought that the way the Romantics lived and died reveals something about their philosophies.

42 Enz $§ 408,162$.

${ }^{43}$ Hegel only writes for an audience that accepts that contradiction is a problem. My conception of an insane person departs from Hegel's more mundane conception of a 'mentally deranged' who still 'has a lively feeling of the contradiction between his merely subjective presentation and objectivity. He is however unable to rid himself of this presentation and is fully intent either on actualizing it or demolishing what is actual` (Enz $\$ 408,176)$. It seems that Hegel cannot envisage an agent who is not moved at all by a contradiction to adapt her views. Even the beautiful soul who 'breaks down into madness' still has 'consciousness of this contradiction in its unreconciled immediacy', which leads it to "give up its grim adherence to its being-for-itself (PoM §668, 491). Hegel presumably would not think of a person who fails to feel the pressure to resolve contradictions as an agent, since agency requires the capacity to plan ahead and to hold distinct views. Agents who could hold and act on contradictory beliefs and goals without seeing any need to be consistent in their beliefs and actions and who are thus unable to limit themselves to distinct beliefs and goals lack this crucial capacity. 
question: Can I latch on to something in that agent to criticise her and, if I can, could that criticism lead to a change of mind? ${ }^{44}$ This might not give us a sharp distinction between evil and insanity for all cases, but as I have pointed out, this fuzziness might be grounded in the very phenomenon of evil.

(ii) In sec.III, I argued that, according to the conception of evil as a distortion of communication, evil and moral badness are separate phenomena. Evil is not a question of actions and their consequences, but of attitudes to oneself. This implies that an evil agent might believe that his true self is a philanthropist and spend his time volunteering for the needy. He might, however, also have a different, much less benevolent, conception of his true self, and what this conception is, is not up for rational debate. Hegel's provocative notion is that there is something deeply deficient even with a self-sacrificing philanthropist if this 'philanthropist' helps others simply because he takes being a philanthropist to be his true self no matter what. Hegel believes that there is something fundamentally wrong with a person who effectively cannot be criticised from an external standpoint and who does not understand that an immediate and private feeling that something is true or right is insufficient justification for that feeling. ${ }^{45}$

It is often assumed that if something is evil it must also be morally wrong. ${ }^{46}$ This is not the case for Hegel. According to his conception, evil agents might do less harm (in terms of consequences) than morally bad agents, and the evil agent might not be morally bad at all if we understand moral badness in terms of rights violations or infliction of harm. In fact, the evil agent might be, according to Hegel's own paradigm, a poet, novelist and philosopher who is deeply dissatisfied with the human condition in the age of industrialization and enlightenment and who sees society as a source of alienation. One might object that Hegel's account of evil does not sufficiently match our intuitions about who counts as evil. What I am talking about in this paper might rather capture a specific moral and intellectual vice but not evil. ${ }^{47}$

44 The way to engage, and maybe even cure, an insane person is thus not through internal criticism but through medication and therapy that requires specialized medical and psychological training and expertise.

45 Suspicion against philanthropists based on their motives is of course not restricted to Hegel. See Kant's famous criticism of the 'friend of humanity' who helps others albeit for the wrong reasons and whose actions thus lack moral worth (AA IV:398-9). However, Kant, unlike Hegel, does not go so far as to think that this agent would be evil, at least not in a sense other than radical evil, which pertains to all of us (see below). Hegel would maintain that the philanthropist who is following nothing but her own subjectivity is still criticisable since her attitude betrays that ' $[\mathrm{i}] \mathrm{t}$ is not the thing which is excellent, it is I who am excellent and master of both law and thing' (EPR \$140, 279). I cite Kant according to Kant (1900 ff.): AA volume:page. Translations are my own.

46 See, for instance Formosa, 'Evils, Wrongs and Dignity', p. 241, who believes that a theory of evil and a theory of moral wrongness should be compatible in the sense that everything a theorist considers evil, she should also consider morally wrong.

47 Many people in the debate argue that an agent must inflict substantial harm on others to be considered evil - see Kekes, Facing Evil, p. 4, John Kekes, The Roots of Evil (Ithaca, NY: Cornell University Press, 2005), p. 1, Card, The Atrocity Paradigm, p. 3, Formosa, 'A Conception of Evil', Zachary Goldberg, 'Evil, 'Evil', and Taking Responsibility', in Wozu ist das Böse gut?, edited by Birgit Recki (Münster: Mentis, 2016), at pp. 17-36. Daniel Haybron, 'Moral Monsters and Saints', The Monist, $85: 2$, pp. $260-284$, at p. 264 , however, argues intention or wish to do so are sufficient. An evil agent 
However, understanding evil as a distortion of communication matches at least some of our intuitions about evil, such as that evil is a matter of an agent's character, that evil is different from moral badness, that evil agents feel no remorse, and that they are beyond normal forms of criticism. Furthermore, this supposed vice Hegel calls 'evil' is more fundamental than other vices since an agent in its grasp cannot be criticized by others in ways even morally bad agents can. This vice extends to everything the agent does and thinks. It is thus more than a simple vice with a specific scope (such as consumption of food, the correct reaction when in danger, etc.). It is, rather, an account of the possibility of a specific form of evil than of what we think of as evil in itself. In this Hegel's account is similar to Kant who considers radical evil to be a freely chosen yet natural propensity to violate the moral law. ${ }^{48}$ Evil here is a condition of the possibility of moral violations and of moral badness. For Kant, agents could be radical evil without ever doing anything morally bad (such as violating other's rights). Given human fallibility this is of course a purely hypothetical option, yet it is significant that evil for Kant (as well as for Hegel) does not necessarily imply moral badness. ${ }^{49}$

With his provocative charge that Romanticist subjectivism is evil, Hegel aims to articulate the uneasiness we feel when interacting with an agent who is not susceptible to rational criticism in the same way that we are. Evil means that there is an essential randomness at the basis of agents' deliberation. Our abilities to communicate, engage in rational debate, and give and demand reasons, offer no or little protection against these agents. We are at their mercy or at the mercy of their conceptions of themselves in a way that we are not with non-evil agents. When interacting with evil agents there is something not up for debate that should be up for debate and that must be susceptible to rational criticism by others. Evil agents in Hegel's sense could easily commit evil acts as we ordinarily understand it. Moreover, all of them seem to have at least a latent evil to them, as they all take their subjectivity as overriding reason for action, and the content of their subjectivity is ultimately a matter of luck.

\section{Conclusion}

For Hegel evil is a relatively recent stage of human development. There was no evil in the pre-modern world since this period of the development of human culture lacked a notion of subjectivity robust enough for Romanticist subjectivism. However, once the condition for the possibility of evil -a fully developed subjectivity-is achieved, the possibility of evil will always be with us. There is however a remedy: subjectivity, in a rational modern society, is actualized in institutions, such as the State, art, religion, philosophy, and civil

does not necessarily have to cause harm to anyone. Hegel's position is even more non-standard insofar as his evil agent does not even need to intend to harm anyone or wish suffering upon anyone. I am grateful to Brian McElwee and Joe Saunders for this challenge.

48 AA VI:32-7.

49 The connection between evil and moral badness is, however, tighter for Kant than it is for Hegel. For Kant, there is still an internal connection between the concept of evil and that of moral wrongness, as the propensity to radical evil is precisely a propensity to prefer self-love over duty or to violate duty. I am grateful to Seiriol Morgan for discussion of this point. 
society. Hegel's hope is that agents will come to realize that subjectivity is an internal and external actual. Subjectivity is something that modern individuals share and that enables them to establish a specifically modern society, a society that makes space for the actualization of everyone's subjectivity. Under the right external conditions actualizing one's subjectivity thus does not have to be something that requires that we turn away from society and from communication with other agents.

Hegel's theory of evil is challenging because he does not start his theorizing from the usual paradigms of evil. The main weakness of this theory is that he thinks of one specific problem that he finds within romantic philosophy, the idea that all normative content is rooted in one's authentic self and supposedly does not need further justification, as what evil is, regardless of how the ideal of an authentic self is actualized in an individual's life. The strength of his account is that he focuses on a deficiency that tends to be overlooked if we only ask about harm and bad intentions: it is an essential aspect of human interaction that we can discuss with an open mind what others have to say and that others can convince us and that we can convince them. Some agents do not attach the same significance to this open-mindedness and some lack it entirely as well as the capability to critically reflect about their beliefs and to distance themselves from them. These agents should concern us and there is something evil about them, but this is not all there is to this complex phenomenon. ${ }^{50}$

Martin Sticker, Trinity College Dublin stickerm@tcd.ie

\section{Bibliography}

Barry, Brian. 'Extremity of Vice and the Character of Evil', Journal of Philosophical Research, 35 (2010), pp. 25-42.

Beiser, Frederick. The Romantic Imperative. The Concept of Early German Romanticism. Cambridge, Mass.: Harvard University Press, 2003

Behler, E., et. al. (eds.). Kritische Friedrich-Schlegel-Ausgabe. Paderborn: Schöningh, 1979.

50 I am grateful to Seiriol Morgan, Joe Saunders, Zachary Goldberg, James Camien McGuiggan, Daniel Wenz, Brian McElwee, Chris Janaway, Christian Hofmann, Chris Macleod, Vera Flocke, Andre Grahle, Nathan Howard, RenaudGarner, Heather Peterson, David Woods, Stefan Kühnen, Thomas Oehl, Eva Schneider, Nadine Köhne and two anonymous referees for feedback on earlier drafts of this paper. I wish to express my special gratitude to Guido Kreis for awakening my interest in the philosophical significance of the relation between German Idealism and Romanticism in the first place. I am also grateful to Interdisciplinary Net, The Oxford Research Centre in the Humanities, the Southampton Ethics Centre, the German department of University College Cork, Societas Ethica, the International Network Hegel's Relevance, the Vrije Universiteit Amsterdam, the Forschungsnetzwek Transzendentalphilosophie/Deutscher Idealismus, and the Technische Universität Berlin as well as to David Woods, Juliana de Albuquerque and Eva Schneider for providing me with opportunities to present talks on Hegel and evil. I am grateful to my audiences at these occasions. Work on this paper has been financially supported by an Irish Research Council grant, and facilitated by the Philosophy departments of Trinity College Dublin and of the GeorgAugust-Universität Göttingen. 
Bernstein, Richard. Radical Evil. A Philosophical Interrogation. Cambridge, Polity Press, 2002.

Bubner, Rüdiger. 'Zur Dialektischen Bedeutung romantischer Ironie', in Innovationen des Idealismus, edited by Rüdiger Bubner. Göttingen: Vandenhoeck \& Ruprecht, 1995, pp. 152-163.

Card, Claudia. The Atrocity Paradigm. New York: Oxford University Press, 2002.

Firchow, Peter. Friedrich Schlegel's Lucinde and the Fragments . Oxford: Oxford University Press, 1971.

Formosa, Paul. 'A Conception of Evil', The Journal of Value Inquiry 42:2 (2008), pp. 217-239,

Formosa, Paul. 'Evils, Wrongs and Dignity: How to Test a Theory of Evil', The Journal of Value Inquiry 47:3 (2013), pp. 235-253.

Frank, Mandfred. 'Philosophische Grundlagen der Frühromantik', Athenäum, 4 (1994), pp.37-130

Frischmann, Bärbel. Vom transzendentalen zum frühromantischen Idealismus. J.G. Fichte und Fr. Schlegel. Paderborn: Schöningh, 2005.

Garrard, Eve. 'The Nature of Evil', Philosophical Explorations 1:1 (1998), pp. 43-60.

Garrard, Eve.'Evil as an Explanatory Concept', The Monist 85:2 (2002), pp. 320-36.

Goldberg, Zachary. 'Evil, 'Evil', and Taking Responsibility', in Wozu ist das Böse gut?, edited by Birgit Recki. Münster: Mentis, 2016, pp. 17-36.

Göhler, Gerhard. Georg Wilhelm Friedrich Hegel. Frühe politische Systeme. Frankfurt a.M.: Ullstein, 1974.

Haybron, Daniel. 'Moral Monsters and Saints', The Monist, 85:2, pp. 260-284.

Hegel, G. W. F. Gesammelte Werke. Hamburg: Meiner Verlag, 1968ff.

Hegel, G. W. F.Werke (eds. Michel Moldenhauer), Frankfurt a.M.: Suhrkamp, 1970.

Kant, Immanuel. Kant's gesammelte Schriften. Herausgegeben von der Königlich Preußischen Akademie der Wissenschaften. Berlin: Georg Reimer, $1900 \mathrm{ff}$.

Kekes, John. Facing Evil. Princeton: Princeton University Press, 1990.

Kekes, John. The Roots of Evil. Ithaca, NY: Cornell University Press, 2005.

Morton, Adam. On Evil. New York: Routledge, 2004.

Norman, Judith. 'Squaring the Romantic Circle', Proceedings of the Hegel Society of America 14 (2000), pp. 131-144.

Moyar, Dean. Hegel's Conscience. Oxford: Oxford University Press, 2011.

Neiman, Susan. Evil in Modern Thought. An Alternative History of Philosophy. Princeton, Oxford: Princeton University Press, 2002.

Perrett, Roy. 'Evil and Human Nature', The Monist 85:2 (2002), pp. 304-19.

Pinkard, Terry. "Phänomenologie des Geistes" Translation, draft, online at http:/ / terrypinkard.weebly.com/phenomenology-of-spirit-page.html

Pöggeler, Otto. Hegels Kritik der Romantik. Bonn: Bouvier, 1956.

Sticker, Martin and Daniel Wenz. 'System und Systemkritik - Witz und Ironie als philosophische Methode beim frühen Friedrich Schlegel', Philosophisches Jahrbuch 120:1 (2013), pp. 64-81.

Sticker, Martin. 'Hegel und die Wurzel der Humanität', Hegel Jahrbuch (forthcoming).

Wood, Allen. G. W. F. Hegel Elements of the Philosophy of Right, Cambridge, New York: Cambridge University Press, 1991. 